\title{
New species, synonymies, combinations, and records of micropterous Athetini from China (Coleoptera: Staphylinidae: Aleocharinae)
}

\author{
With 60 figures and 1 map
}

VOLKER ASSING ${ }^{1}$

${ }^{1}$ Gabelsbergerstraße 2, 30163 Hannover, Germany. - vassing.hann@t-online.de Published on 2021-06-30

DOI: 10.21248/contrib.entomol.71.1.087-101

\begin{abstract}
Two micropterous and locally endemic species of Bellatheta RouBAL, 1928 and four of Atheta THOMson, 1858, subgenus Microdota Mulsant \& Rey, 1873, from China are described and illustrated: Bellatheta qiliana spec. nov. (Qinghai, Gansu); B. aucticeps spec. nov. (Yunnan: Gaoligong Shan); Atheta (Microdota) clarata spec. nov. (Yunnan: Gaoligong Shan); A. (M.) minica spec. nov. (Sichuan: Songpan env.); A. (M.) qinlingica spec. nov. (Shaanxi: Qinling Shan); A. (M.) biformis spec. nov. (Gaoligong Shan). New illustrations are provided for two previously described Microdota species. One genus-group and one species-group synonymy are proposed: Bellatheta RouBAL, $1928=$ Oroekklina PACE, 1999, syn. nov.; Atheta (Microdota) amischoides Assing, $2006=$ A. (M.) wuliangensis PACE, 2017, syn. nov. Five new combinations are proposed: Bellatheta daxuensis (PACE, 1999), comb. nov., B. excaecata (Assing, 2009), comb. nov., B. proiecta (Assing, 2002), comb. nov., B. smetanai (PACE, 2004), comb. nov. (all of them previously in Oroekklina), and Franzidota geostiboides (Assing, 2011), comb. nov. (ex Platyola Mulsant \& ReY, 1875). Additional records of two species of Bellatheta and of five species of Microdota are reported from China. Catalogues of the Bellatheta species and the micropterous Microdota species recorded from China are provided. Including the new species and synonymies, 15 species of Bellatheta, seven of them micropterous, and 85 of Microdota, 19 of them micropterous, have been reported from China. The Microdota fauna of Taiwan is composed of 13 species, four of them micropterous. The distributions of the micropterous Bellatheta species of China are mapped.
\end{abstract}

\section{Taxonomic acts}

Bellatheta qiliana spec. nov. - urn:lsid:zoobank.org:act:F391FF78-2A4B-4BEA-BB85-85AC8E30FE70 Bellatheta aucticeps spec. nov. - urn:lsid:zoobank.org:act:1A3E6AAA-2C3C-44B8-A911-4F1246774075 Atheta clarata spec. nov. - urn:lsid:zoobank.org:act:EE3C4E47-FEAB-413A-81C7-A063529A5235 Atheta minica spec. nov. - urn:lsid:zoobank.org:act:E325AF25-C1DD-441C-B7D5-AB2ACF109581 Atheta qinlingica spec. nov. - urn:lsid:zoobank.org:act:1590B986-DE95-458C-AFE3-71CC51AB4106 Atheta biformis spec. nov. - urn:lsid:zoobank.org:act:30A8940E-5B8A-4E27-997F-777E8FFF3E80

\section{Key words}

Coleoptera, Staphylinidae, Aleocharinae, Athetini, Bellatheta, Atheta, Microdota, Franzidota, taxonomy, new species, description, new synonymies, new combinations, endemism, wing reduction, China, Taiwan, new records, catalogue, distribution map 


\section{Zusammenfassung}

Zwei ungeflügelte und lokalendemische Arten der Gattung Bellatheta RouBAL, 1928 sowie vier der Gattung Atheta Thomson, 1858, Untergattung Microdota Mulsant \& Rey, 1873, werden aus China beschrieben und abgebildet: Bellatheta qiliana spec. nov. (Qinghai, Gansu); B. aucticeps spec. nov. (Yunnan: Gaoligong Shan); Atheta (Microdota) clarata spec. nov. (Yunnan: Gaoligong Shan); A. (M.) minica spec. nov. (Sichuan: Songpan); A. (M.) qinlingica spec. nov. (Shaanxi: Qinling Shan); A. (M.) biformis spec. nov. (Gaoligong Shan). Für zwei bereits beschriebene Arten werden neue Abbildungen erstellt. Zwei Namen, einer der Gattungs- und einer der Artgruppe, werden synonymisiert: Bellatheta Roubal, 1928 = Oroekklina PaCe, 1999, syn. nov.; Atheta (Microdota) amischoides Assing, $2006=$ A. (M.) wuliangensis PACE, 2017, syn. nov. Fünf Namen werden neu kombiniert: Bellatheta daxuensis (PACE, 1999), comb. nov., B. excaecata (Assing, 2009), comb. nov., B. proiecta (Assing, 2002), comb. nov., B. smetanai (PACE, 2004), comb. nov. (alle bisher in Oroekklina) und Franzidota geostiboides (Assing, 2011), comb. nov. (ex Platyola Mulsant \& Rey, 1875). Weitere Nachweise von zwei Bellatheta- und fünf Microdota-Arten werden aus China gemeldet. Kataloge der aus China bekannten Bellatheta- und ungeflügelten Microdota-Arten werden erstellt. Einschließlich der neu beschriebenen Arten und Synonymien wurden bislang 15 Bellatheta- (davon sieben ungeflügelt) und 85 Microdota-Arten (19 davon ungeflügelt) aus China nachgewiesen. Die Microdota-Fauna Taiwans umfasst 13 Arten, vier davon ungeflügelt. Die Verbreitungsgebiete der brachypteren Bellatheta-Arten Chinas werden anhand einer Karte illustriert.

\section{Schlüsselwörter}

Coleoptera, Staphylinidae, Aleocharinae, Athetini, Bellatheta, Atheta, Microdota, Franzidota, Taxonomie, neue Arten, Beschreibung, neue Synonymien, neue Kombinationen, Endemismus, Flügelreduktion, China, Taiwan, neue Nachweise, Katalog, Verbreitungskarte

\section{Introduction}

China is known to host a huge number of micropterous Staphylinidae. Some megadiverse genera such as Nazeris FaUvel, 1873 and Lathrobium Gravenhorst, 1802 of the Paederinae and Othius Stephens, 1829 of the Staphylininae are exclusively (Nazeris), nearly exclusively (Lathrobium), or predominantly (Othius) represented in this region by wingless species, all of them epigeic inhabitants of the litter layer of montane forests, subalpine, and alpine habitats and regionally or locally endemic to individual mountains or mountain ranges. Among the Chinese provinces, Yunnan and Sichuan generally host the greatest diversity of micropterous species. Genera with predominantly flighless species are also found in various taxa of the Aleocharinae, e.g., Leptusa KRAATZ, 1856 (Homalotini), Autalia LeACH, 1819 (Autaliini), and the subgenus Oncosomechusa PACE, 1982 of the genus Masuria CAMEron, 1939 (Masuriini).

The aleocharine tribe Athetini, by contrast, is primarily represented by r-selected, macropterous taxa and, in China, includes only relatively few genera with a larger number of micropterous species, among them Bellatheta Roubal, 1928, Oroekklina PACE, 1999, and the subgenus Microdota Mulsant \& Rey, 1873 of the genus Atheta Thomson, 1858. According to Schülke \& Smetana (2015) and an unpublished manuscript of this catalogue updated until the end of 2019 (SCHÜLKE unpubl.), Bellatheta is represented in the Palaearctic region by a total of 39 species, nine of them recorded from China. Oroekklina includes four species, all of them micropterous and endemic in Yunnan or Sichuan. The diverse subgenus Microdota is represented in the Palaearctic region by 285 species, 82 of them recorded from China and 13 from Taiwan.

The present study is mainly based on material of Bellatheta and Microdota made available to me by Aleš Smetana (Ottawa) and Michael Schülke (Berlin). Additional specimens were collected during a joint field trip to China conducted by Michael Schülke, David Wrase, and the author in 2012.

\section{Material and methods}

The material examined in the course of the present study is deposited in the following public and private collections:

\section{CAS Chinese Academy of Sciences, Beijing}

CNC Canadian National Collection of Insects, Arachnids and Nematodes (A. Brunke, A. Smetana)

MNB Museum für Naturkunde, Berlin (coll. Schülke)

cAss author's private collection

The morphological studies were conducted using Stemi SV 11 (Zeiss) and Discovery V12 (Zeiss) microscopes, and a Jenalab compound microscope (Carl Zeiss Jena). The images were taken and processed using digital cameras (Axiocam ERc 5s, Nikon Coolpix 995), as well as Labscope and Picolay stacking software. The map was created using MapCreator 2.0 software.

Body length was measured from the anterior margin of the labrum to the apex of the abdomen, the length of the 
forebody from the anterior margin of the labrum to the posterior margin of the elytra, head length from the anterior margin of the clypeus to the posterior constriction of the head, elytral length at the suture from the apex of the scutellum to the posterior margin of the elytra, and the length of the aedeagus from the apex of the ventral process to the base of the aedeagal capsule. The "parameral" side (i.e., the side where the sperm duct enters) is referred to as the ventral, the opposite side as the dorsal aspect.

\section{Results}

\section{Genus Bellatheta RouBAL, 1928}

Oroekklina PACE, 1999: 378; syn. nov.

When describing Oroekklina, PACE (1999) originally included only the micropterous type species $O$. daxuensis PACE, 1999, which was described in the same article, based on a unique female from Daxue Shan in Sichuan. He indicated the tarsal formula as $4,4,5$, but observed that the mouthparts, the spermatheca, and "altri numerosi caratteri" suggested that the genus was close to
Atheta of the Athetini. Nevertheless, Oroekklina was subsequently placed in the subtribe Bolitocharina of the tribe Homalotini (Schülke \& Smetana 2015). Three additional species were described in, or transferred to, Oroekklina by Assing (2002, 2009) and PACE (2004), all of them micropterous and from China (Sichuan and Yunnan provinces). A revision of all the species previously included in Oroekklina, including the type species, revealed that the tarsal formula is not $4,4,5$ as indicated in the original description, but $4,5,5$. Thus, no principal difference remains distinguishing Oroekklina from Bellatheta, whose monophyly is constituted particularly by the synapomorpic structure of the median lobe of the aedeagus (ventral process deeply bifid), a condition also shared by the species previously in Oroekklina. As a consequence, Oroekklina is placed in synonymy with the senior name Bellatheta, resulting in four new combinations (see checklist below).

Including the new species described below, 15 species of Bellatheta, seven of them micropterous, are currently known from China. The micropterous representatives of the genus are distributed in West China, from Qinghai and Gansu in the north to Yunnan in the south (Map 1), with four of the species locally endemic in Yunnan, two in Sichuan, and one in Qilian Shan (Qinghai, Gansu).

\section{Checklist of Bellatheta species recorded from China}

The species are listed alphabetically. Species recorded from Taiwan are not included.

The literature references are abbreviated as follows: A02 = Assing (2002); A05 = Assing (2009); A09 = Assing (2009); A11 = Assing (2011); App = Assing (present paper); P93 = PACE (1993); P98a = PACE (1998a); P99 = PACE (1999); P04 = PACE (2004); P11a = PACE (2011a).

Micropterous species are marked with a “+”. Species of doubtful generic assignment are marked with an asterisk (“*”).

\begin{tabular}{|c|c|c|}
\hline Species & Distribution & References \\
\hline +aucticeps spec. nov. & China: Yunnan: Gaoligong Shan & App \\
\hline bellicosa (PACE, 2004) & China: Sichuan & P04 \\
\hline $\begin{array}{l}{ }^{*} \text { chinensis }(\mathrm{PACE}, 1993) \\
=\text { xinjiangensis }(\mathrm{PACE}, 2004)\end{array}$ & China: Xinjiang & P93, P04 \\
\hline +daxuensis (PACE, 1999), comb. nov. & China: Sichuan: Daxue Shan, Gongga Shan & A02, P99, App \\
\hline +diacangica Assing, 2011 & China: Yunnan: Diancang Shan & A11 \\
\hline +excaecata (Assing, 2009), comb. nov. & China: Yunnan: Gaoligong Shan & A09, A11 \\
\hline $\begin{array}{l}\text { gansuica (AssING, 2005) } \\
=\text { chinensis (PACE, 1998) }\end{array}$ & China: Gansu & A05, P98a \\
\hline granulosa (PACE, 2004) & China: Sichuan, Shaanxi, Gansu & App, P04 \\
\hline huamontis PACE, 2011 & China: Shaanxi & P11a \\
\hline+ proiecta (Assing, 2002), comb. nov. & China: Sichuan: Shalui Shan & A02 \\
\hline +qiliana spec. nov. & China: Qinghai, Gansu & App \\
\hline ruficollis PACE, 2011 & China: Yunnan & P11a \\
\hline +smetanai (PACE, 2004), comb. nov. & China: Yunnan: Xue Shan & A11, P04 \\
\hline tibetana PACE, 2011 & China: Sichuan & P11a \\
\hline *yunnanensis PACE, 2011 & China: Yunnan & P11a \\
\hline
\end{tabular}




\section{Bellatheta daxuensis (PACE, 1999), comb. nov.} (Map 1)

Material examined: China: Sichuan: 4 ㅇ ㅇ, Gongga Shan, NE-slope, $29^{\circ} 55^{\prime} \mathrm{N}, 102^{\circ} 01^{\prime} \mathrm{E}, 4140 \mathrm{~m}, 13 . \mathrm{VI} .2011$, leg. Grebennikov (CNC, cAss); 1 , Gongga Shan, NE-slope, $29^{\circ} 56^{\prime} \mathrm{N}, 101^{\circ} 59^{\prime} \mathrm{E}, 3550 \mathrm{~m}, 17 . \mathrm{VI} .2011$, leg. Grebennikov (CNC).

The original description is based on a unique female from Daxue Shan (PACE 1999). The species was subsequently recorded again and the male sexual characters were illustrated by Assing (2002). The above specimens represent the first records from Gongga Shan. The currently known distribution is illustrated in Map 1.

\section{Bellatheta qiliana spec. nov. urn:Isid:zoobank.org:act:F391FF78-2A4B-4BEA-BB85-85AC8E30FE70 (Figs 1-3, 15-23, Map 1)}

Type material: Holotype $\sigma^{\star}$ : "CHINA: Qinghai Prov. [CH11-11a], Lang Shi Dang Jing Qu (Park) $75 \mathrm{~km}$ NW Honggu, $2925 \mathrm{~m}, 36^{\circ} 54^{\prime} 05.2^{\prime \prime N}, 102^{\circ} 21^{\prime} 07.1 " \mathrm{E}$, creek valley on overgrown scree, Populus and Betula forest with Rhododendron, litter sifted between rocks, 28.VI.2011, leg. M. Schülke / Holotypus o Bellatheta qiliana sp. n., det. V. Assing 2020" (MNB). Paratypes: 8 exs.: same data as holotype (MNB, cAss); 6 exs.: same data, but leg. Wrase (MNB); 50 exs.: "CHINA: Qinghai Prov. [CH11-11], Lang Shi Dang Jing Qu (Park) 75 km NW Honggu, $2896 \mathrm{~m}, 36^{\circ} 54^{\prime} 08.8^{\prime \prime} \mathrm{N}, 102^{\circ} 21^{\prime} 16.9^{\prime \prime} \mathrm{E}$, creek valley on overgrown scree, Populus and Betula forest, litter sifted between rocks, 28.VI.2011, leg. M. Schülke" (MNB, cAss); 28 exs.: "CHINA: Qinghai Prov. [CH11-19], road $301 \mathrm{~km} \mathrm{180,} 43 \mathrm{~km}$ ESE Men Yuan, 3709'32.6"N, 102 $02^{\prime} 06.0^{\prime \prime} \mathrm{E}, 2704 \mathrm{~m}$, creek valley with Picea, Salix, Populus, Betula, litter and moss sifted, 5.VII.2011, leg. M. Schülke” (MNB, cAss); 67 exs.: same data, but leg. Wrase (MNB, cAss); 9 exs: "CHINA: Qinghai Prov. [CH11-18], Daban Shan, Pass 19 km WSW Men Yuan, southern ramp, shrubbery overhead, $37^{\circ} 22^{\prime} 23.8^{\prime \prime} \mathrm{N}, 101^{\circ} 24^{\prime} 22^{\prime \prime} \mathrm{E}, 3522-3550 \mathrm{~m}$, litter \& moss sifted, 4.VII.2011, leg. M. Schülke" (MNB, cAss); 1 ㅇ "CHINA: Qinghai Prov. [CH11-17], Daban Shan, Pass $19 \mathrm{~km}$ WSW Men Yuan, 3750-3800 m, 37²21'11.8"N, $101^{\circ} 24^{\prime} 24.7^{\prime \prime} \mathrm{E}$, alpine cirque, stony pasture with slope springs, under stones, 4.VII.2011, leg. M. Schülke" (MNB); 1 ㅇ: "CHINA: Qinghai Prov. [CH11-08a], Daban Shan, $60 \mathrm{~km}$ NW Honggu, 36² $49^{\prime} 10.7^{\prime \prime}$, $102^{\circ} 31^{\prime} 22.8^{\prime \prime} \mathrm{E}, 2366-2400 \mathrm{~m}$, mixed forest (Betula, Populus, Picea), dead wood, litter sifted, 11.VII.2011, leg. M. Schülke" (cAss); 11 exs: “CHINA: Gansu Prov. [CH11-13d], Lenglong Ling Mts., $80 \mathrm{~km}$ NNW Honggu, 3703'50.3"N, 102 39'57.2"E, 3392 m, alpine pasture with Rhododendron, litter, grass roots sifted, 1.VII.2011, leg. M. Schülke" (MNB, cAss); 1 ex.: same data, but "[CH11-13], ..., 30.VI.2011" (cAss); 7 exs:
"CHINA: Gansu Prov. [CH11-13b], Lenglong Ling Mts., $80 \mathrm{~km}$ NNW Honggu, 3703'47.0"N, 102³9'32.6"E, $3439 \mathrm{~m}$, alpine pasture with Rhododendron and Azalea, litter sifted, 1.VII.2011, leg. M. Schülke” (MNB, cAss); 7 exs: "CHINA: Gansu Prov. [CH11-14], Lenglong Ling

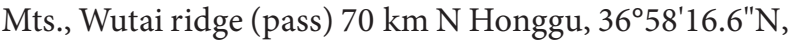
$102^{\circ} 48^{\prime} 03.6^{\prime} \mathrm{E}, 3530 \mathrm{~m}$, stony alpine past with Rhodod. and Azalea, litter \& moss sifted, 2.VII.2011, leg. M. Schülke" (MNB, cAss); 7 exs: "CHINA: Gansu Prov. [CH11-27a], Lenglong Ling Mts., 60 km NNW Honggu, Jin Sha Gorge, mixed forest (Picea, Populus, Betula), 3651'56.9"N, 102³8'55.3"E, litter, moss, mushrooms sifted, 14./15.VII.2011, leg. M. Schülke" (MNB).

Etymology: The specific epithet is an adjective derived from Qilian Shan, the name of the vast mountain range where this species was collected.

Description: Body length 2.4-3.3 mm; length of forebody $1.0-1.2 \mathrm{~mm}$. Habitus as in Figs 1-2. Colouration variable: head reddish to black; pronotum reddish to black; elytra reddish to dark-brown; abdomen usually blackish with the apex (segments VIII-X) more or less distinctly paler; legs yellow, rarely slightly darker; antennae reddish.

Head (Fig. 3) approximately as long as broad; punctation very fine and rather sparse; interstices with distinct microreticulation. Eyes small and nearly flat, composed of approximately ten ommatidia. Antennae moderately incrassate; antennomeres IV weakly transverse, $\mathrm{V}-\mathrm{X}$ of increasing width and increasingly transverse, $\mathrm{X}$ nearly twice as broad as long.

Pronotum (Fig. 3) of variable shape, usually 1.051.15 times as broad as long and 1.05-1.15 times as broad as head, broadest in anterior half, and more or less distinctly tapering posteriad; punctation and microsculpture similar to those of head; pubescence directed anteriad along midline.

Elytra (Fig. 3) approximately half as long as pronotum; punctation fine, but more distinct than that of head and pronotum; interstices with microsculpture. Hind wings completely reduced.

Abdomen broader than elytra; punctation fine and rather sparse; interstices with distinct microreticulation composed of predominantly transverse meshes on anterior tergites and of isodiametric meshes on posterior tergites; posterior margin of tergite VII without palisade fringe; tergite VIII (Fig. 18) without distinct sexual dimorphism, posterior margin broadly convex.

$o^{\star}$ : sternite VIII (Fig. 17) oblong, much longer than tergite VIII, and with strongly convex posterior margin; median lobe of aedeagus $0.35-0.40 \mathrm{~mm}$ long and shaped as in Figs 15-16.

ㅇ: sternite VIII (Fig. 19) transverse, posterior margin broadly convex and with moderately modified marginal setae; spermatheca (Figs 20-23) with proximal portion of somewhat variable length. 


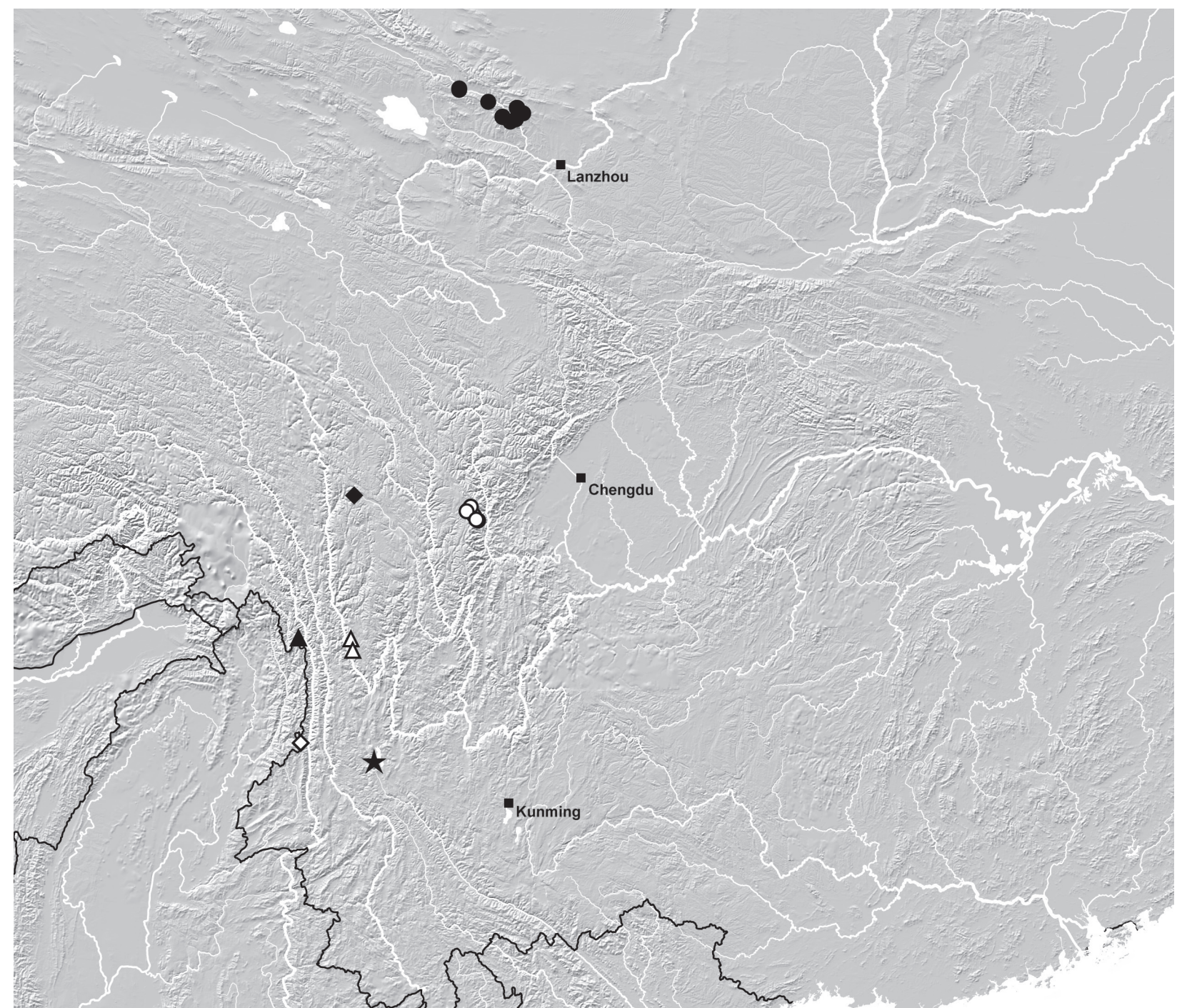

Map 1: Distributions of micropterous Bellatheta species in China: B. qiliana (black circles); B. proiecta (black diamond); B. daxuensis (white circles); B. aucticeps (black triangle); B. smetanai (white triangles); B. excaecata (white diamond); B. diacangica (black star).

Comparative notes: Bellatheta qiliana is distinguished from other micropterous representatives of the genus by the primary sexual characters. In external appearance and the shape of the spermatheca, it is most similar to $B$. daxuensis. If differs from this species by larger body size, less dark colouration of the body and of the legs, a more robust habitus, a relatively smaller head, a more oblong and posteriorly more convex male sternite VIII, a less transverse female sternite VIII, and a spermatheca of slightly different shape. For illustrations of other micropterous Bellatheta species reported from China see PACE (2004) and Assing (2002, 2009, 2011).

Distribution and natural history: The species was collected in numerous localities in Qilian Shan in the border region between Qilian Shan and Gansu provinces, China (Map 1). The specimens were sifted from litter, moss, and grass roots in mixed forests and alpine pastures at altitudes between approximately 2400 and $3800 \mathrm{~m}$. One specimen was found under a stone.

\section{Bellatheta aucticeps spec. nov.}

urn:Isid:zoobank.org:act:1A3E6AAA-2C3C-44B8-A911-4F1246774075 (Figs 4-5, 24, Map 1)

Type material: Holotype o: "P.R. CHINA, Yunnan, E slope N Gaoligongshan, N27²7'22.1" E98 32'17.7", 24.v.2010, 3027 m, sifting20, V. Grebennikov / Holotypus + Bellatheta aucticeps sp. n., det. V. Assing 2020" (CAS).

Etymology: The specific epithet is an adjective composed of the Latin adjective auctus (enlarged) and the suffix -ceps (of the head). It alludes to the large head in relation to the pronotum and elytra.

Description: Body length $2.6 \mathrm{~mm}$; length of forebody $1.0 \mathrm{~mm}$. Habitus as in Fig. 4. Colouration: forebody pale-reddish; abdomen brown with yellowish apex; legs yellow; antennae reddish-yellow.

Head (Fig. 5) 1.1 times as broad as long, large in relation to pronotum; median dorsal portion impressed and with 

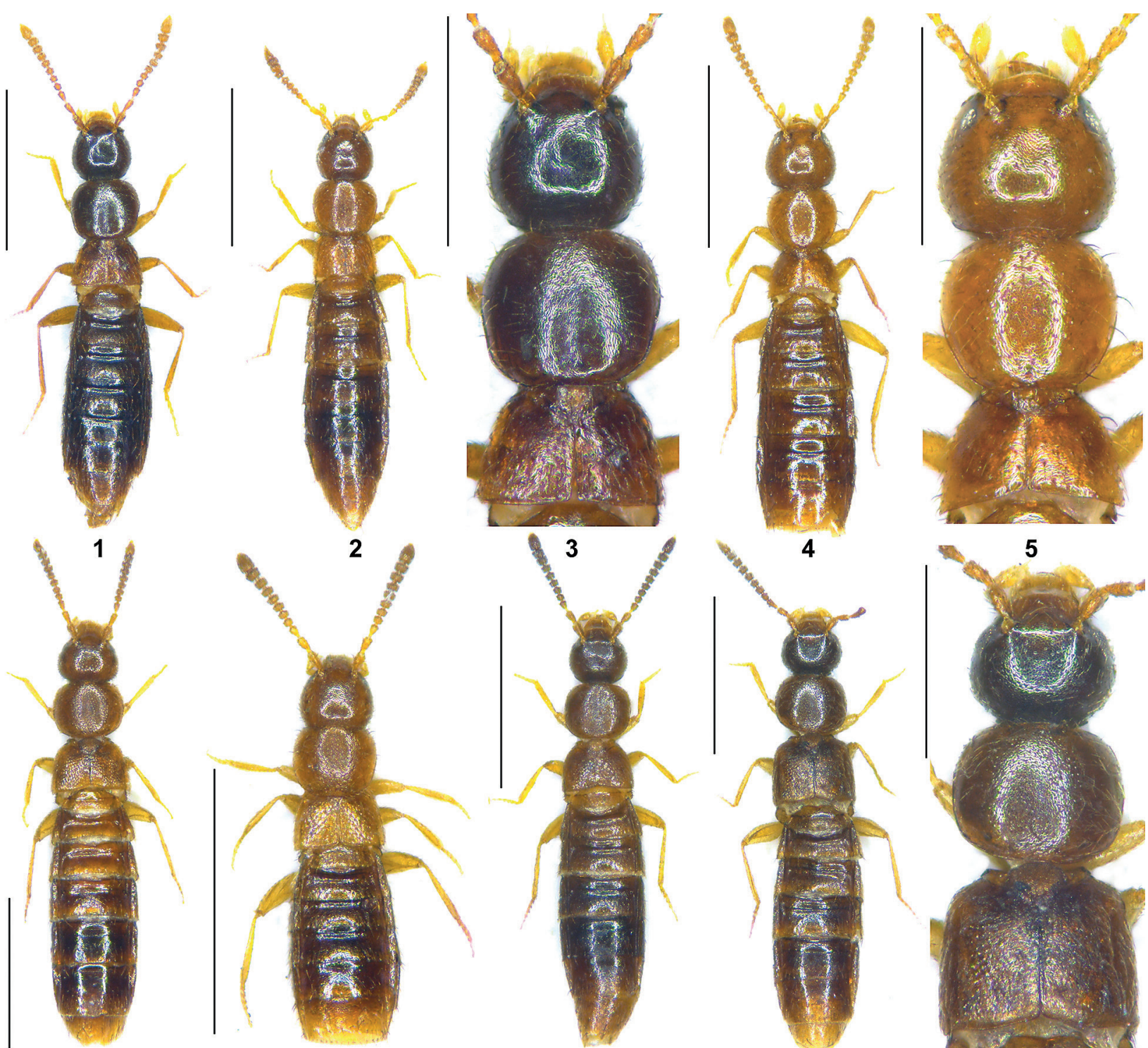

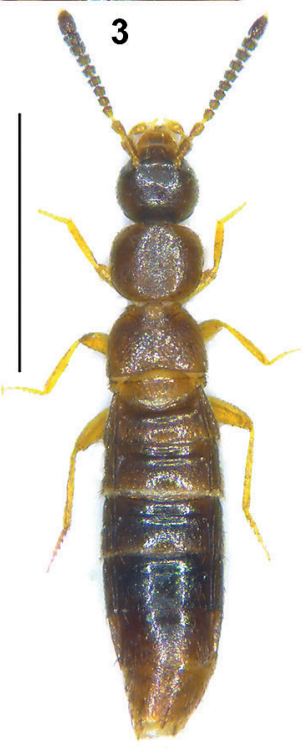

8

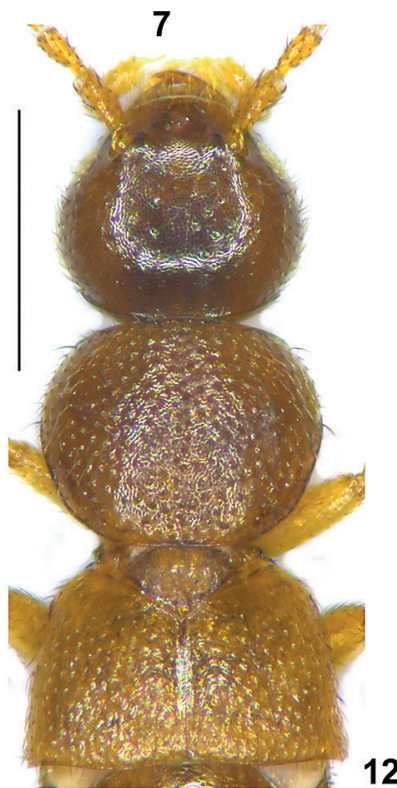

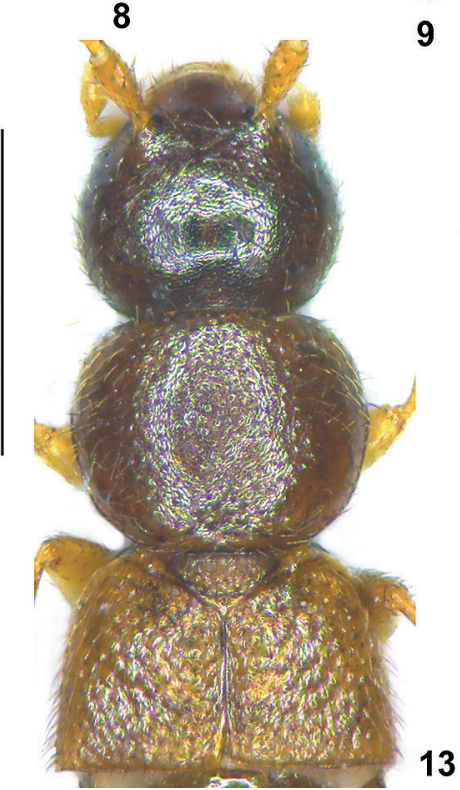

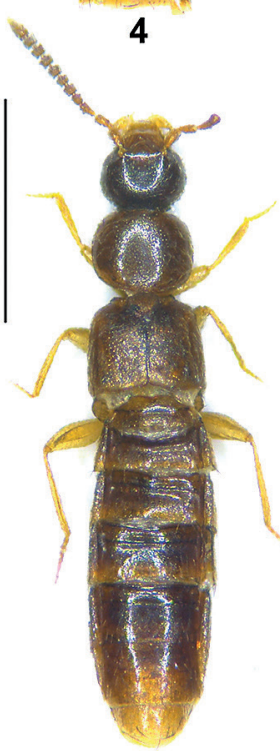

9

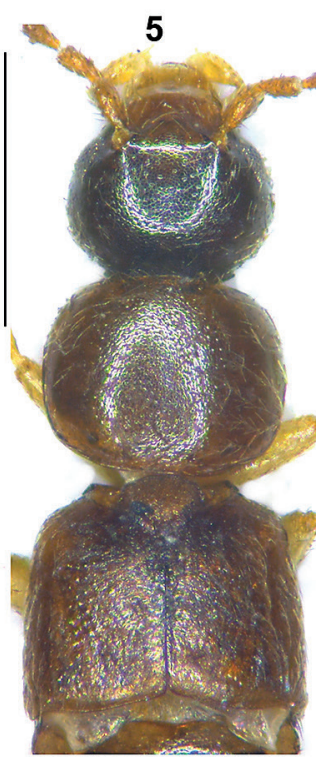

10

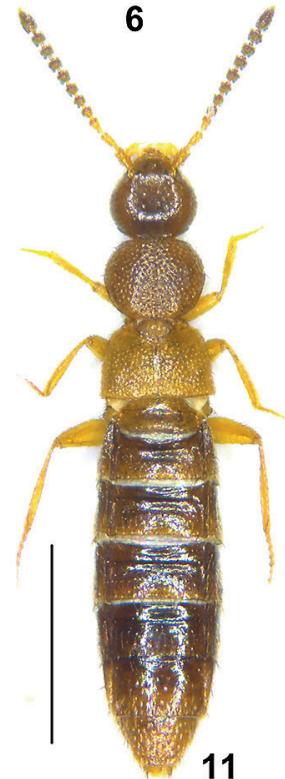

Figs 1-14: Bellatheta qiliana (1-3), B. aucticeps (4-5), Atheta peinantamontis (6), A. clarata (7), A. minica (8), A. qinlingica (9-10), and $A$. biformis (11-14; 11-12, 14: male; 13: female). 1-2, 4, 6-9, 11 - habitus; 3, 5, 10, 12-13 - forebody; 14 - abdomen. Scale bars: $1-2,4,6-9,11: 1.0 \mathrm{~mm} ; 3,5,10,12-14: 0.5 \mathrm{~mm}$. 

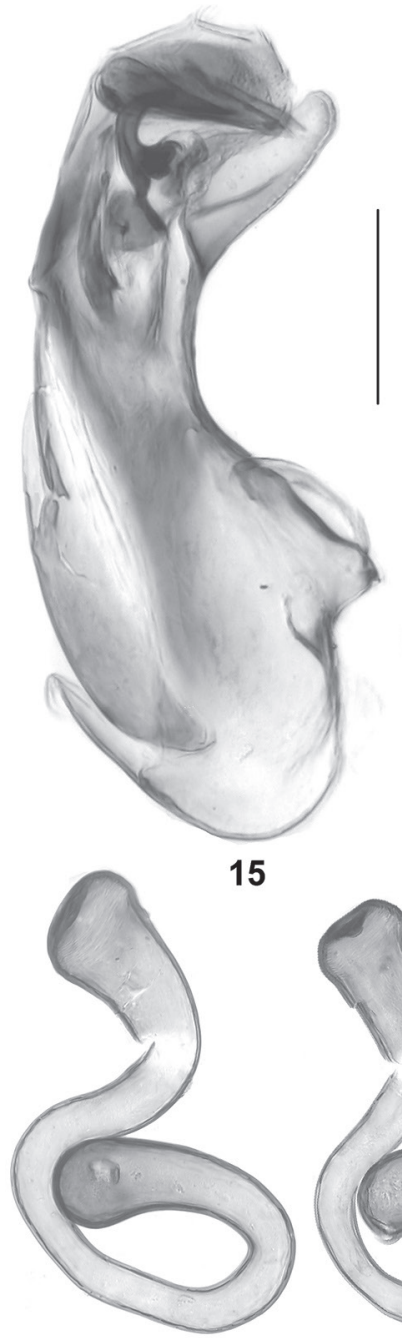

20

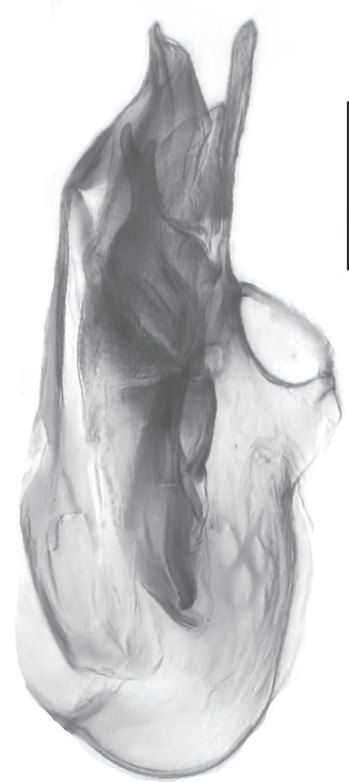

27

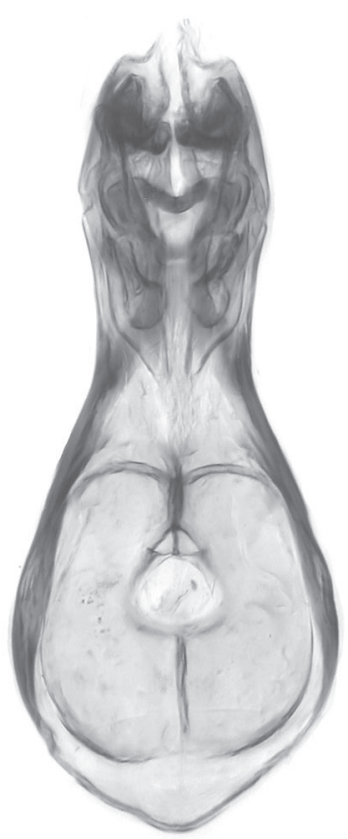

16
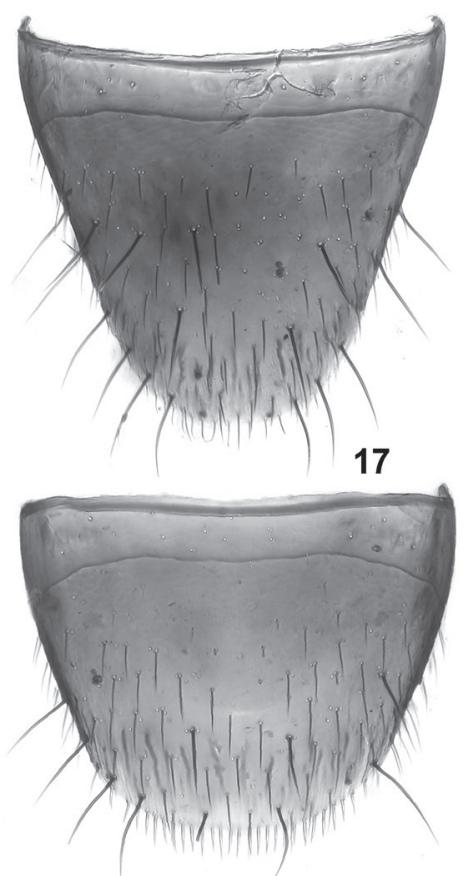

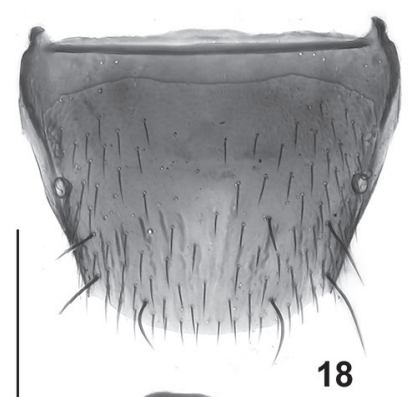

18

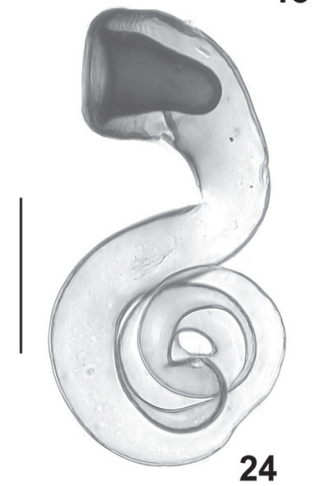

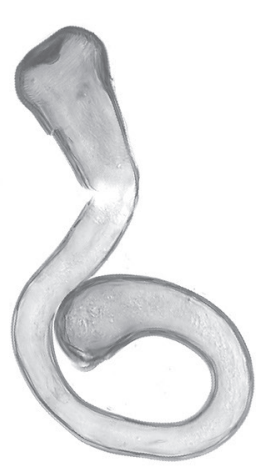

21

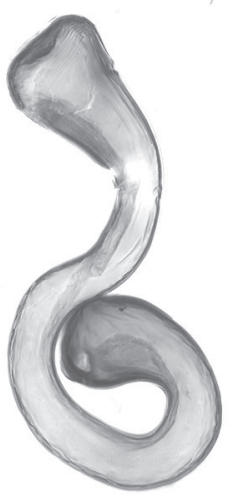

22
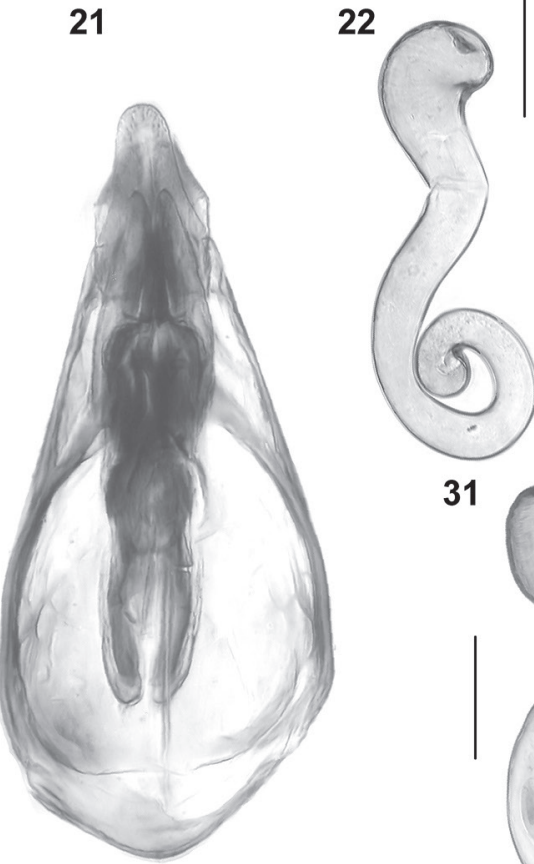

28

19

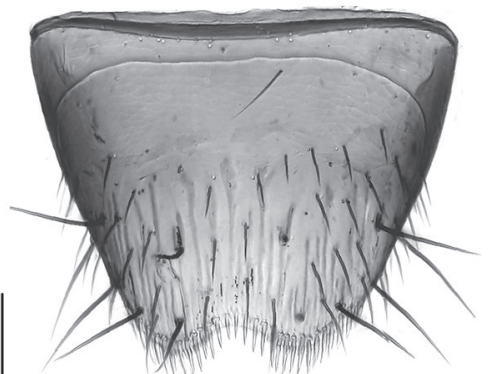

25

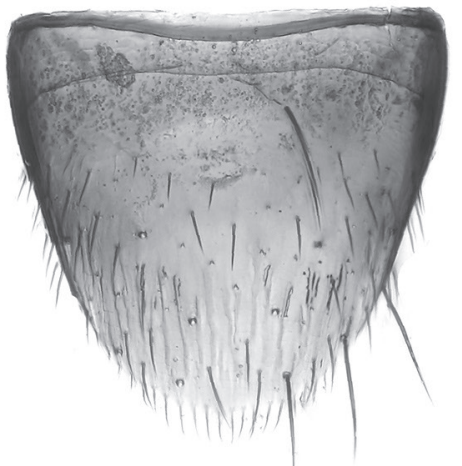

29

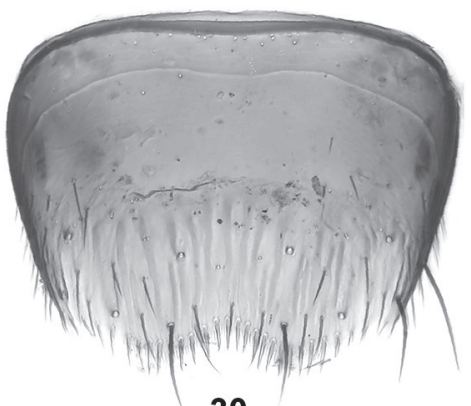

30

Figs 15-32: Bellatheta qiliana (15-23), B. aucticeps (24), Atheta miriapex (25-26), and A. peinantamontis (27-32). 15-16, 27-28 - median lobe of aedeagus in lateral and in ventral view; 17, 29 - male sternite VIII; 18 - female tergite VIII; 19, 25, 30 - female sternite VIII; 20-24, 26, 31-32 - spermatheca. Scale bars: 17-19, 25, 29-30: 0.2 mm; 15-16, 20-24, 26-28, 31-32: $0.1 \mathrm{~mm}$. 


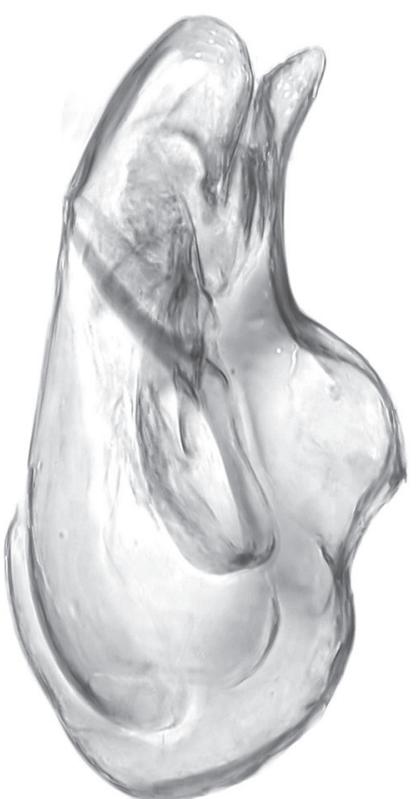

33

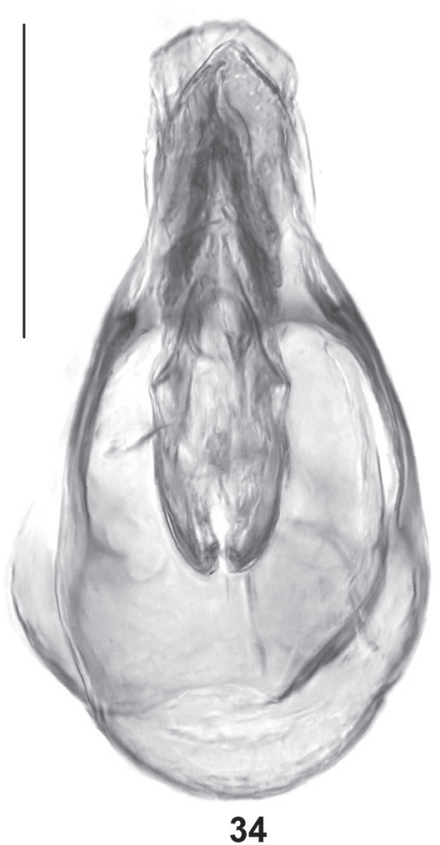

34
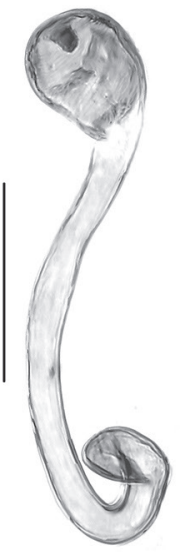

38

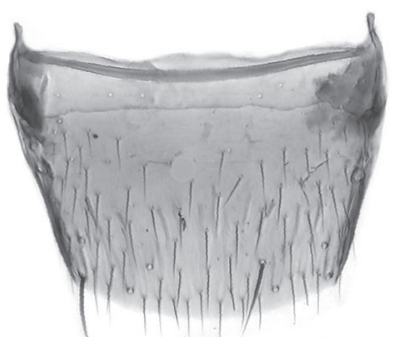

35

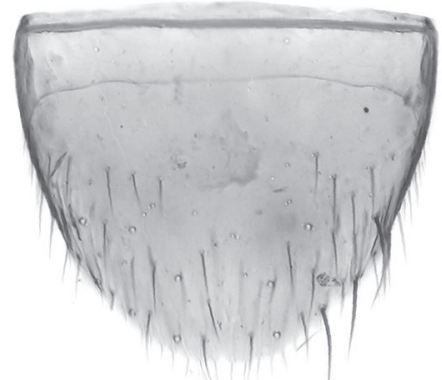

36

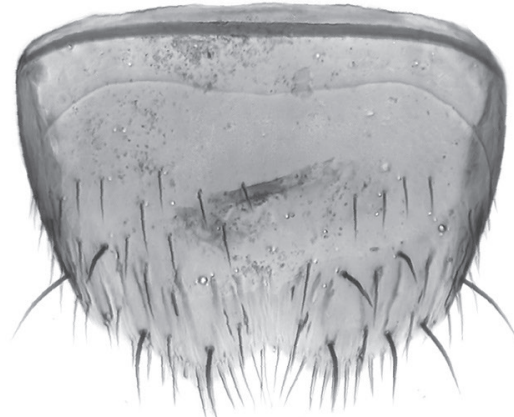

37

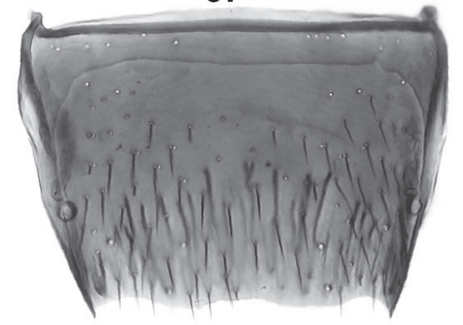

43

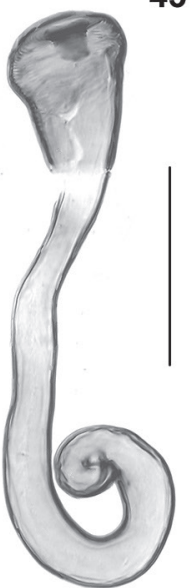

45

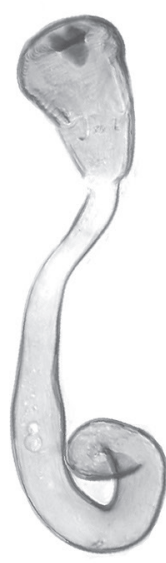

46

Figs 33-46: Atheta clarata (33-38) and A. minica (39-46). 33-34, 39-41 - median lobe of aedeagus in lateral and in ventral view; 35 - male tergite VIII; 36, 42 - male sternite VIII; 37, 44 - female sternite VIII; 38, 45-46 - spermatheca; 43 - female tergite VIII. Scale bars: 35-37, 42-44: $0.2 \mathrm{~mm} ; 33-34,38-41,45-46: 0.1 \mathrm{~mm}$. 


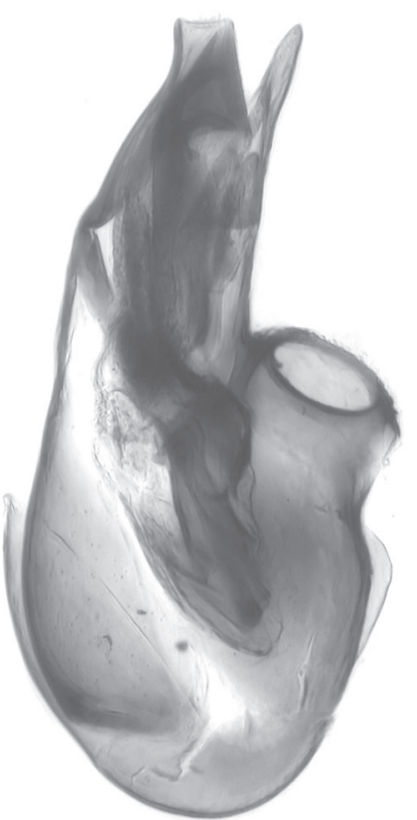

47

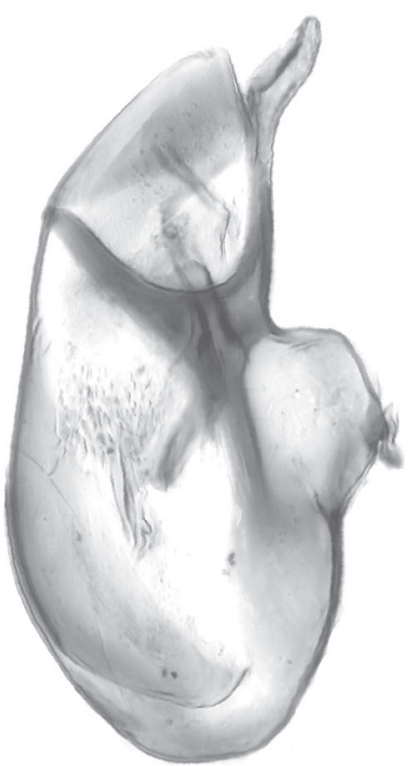

52

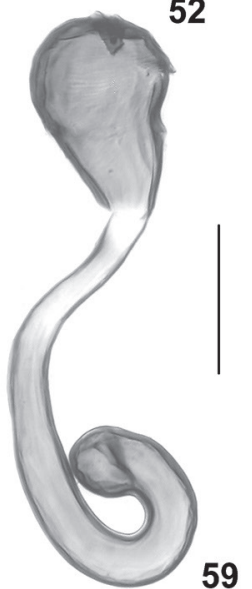

59

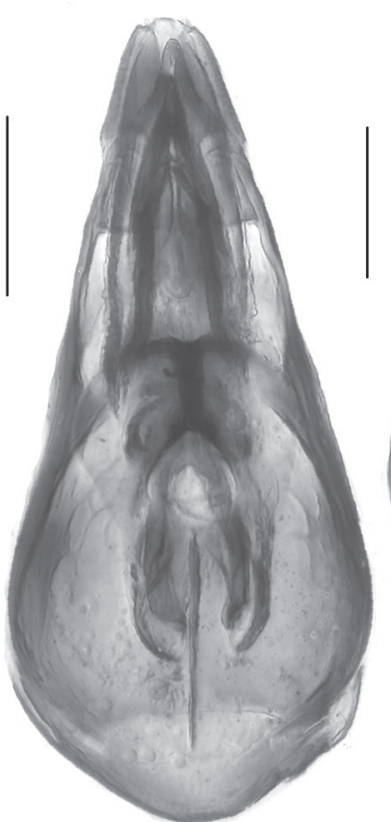

48

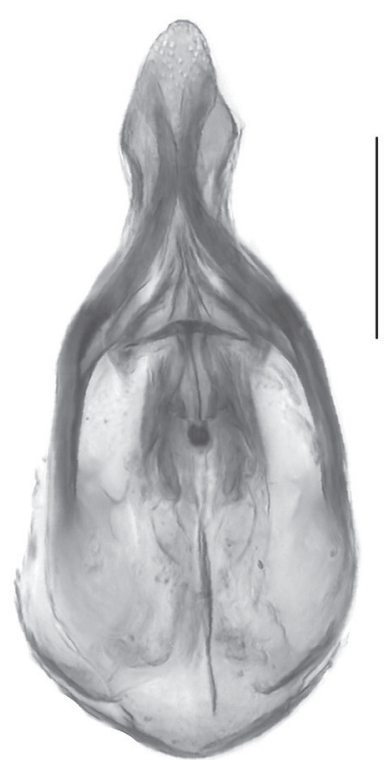

53

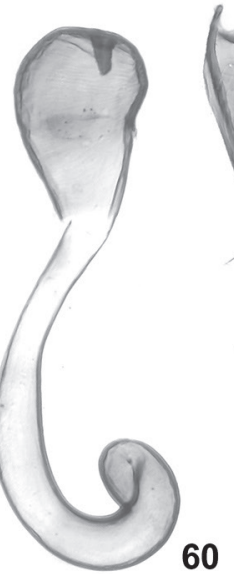

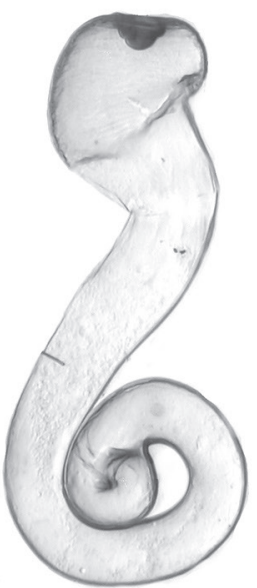

51
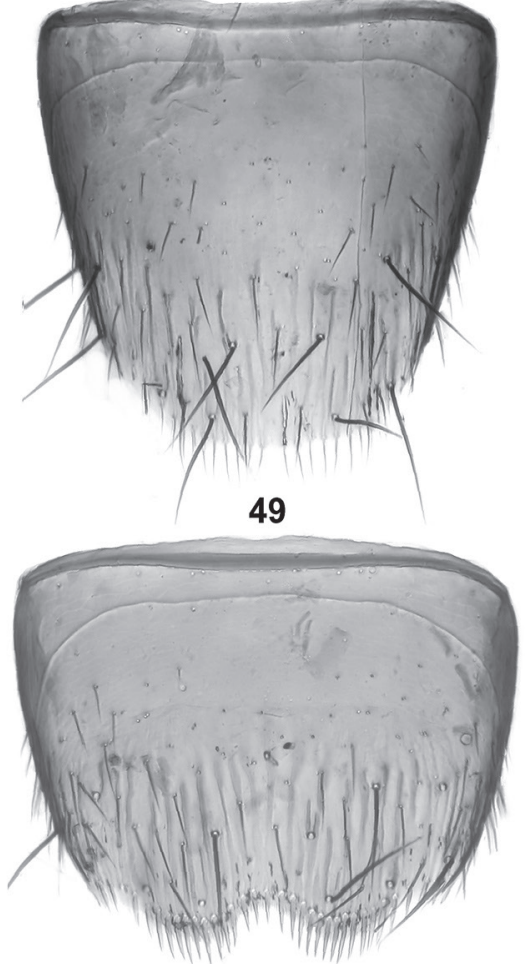

50

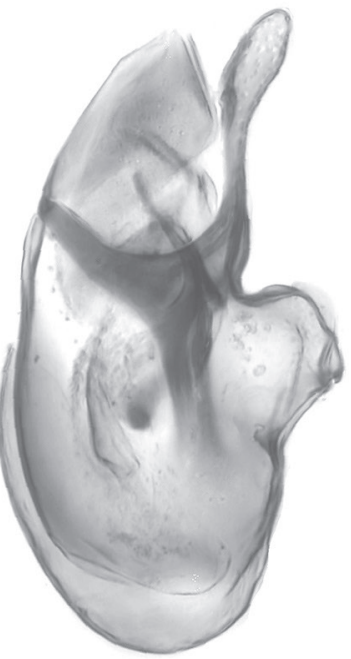

54

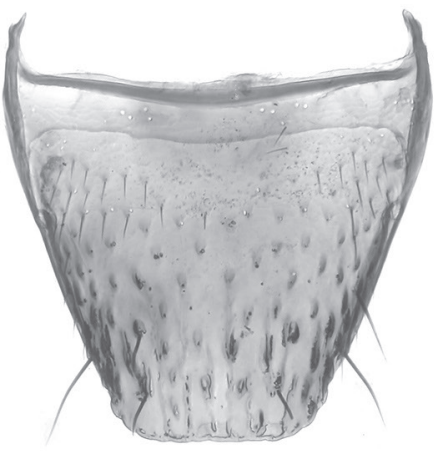

55

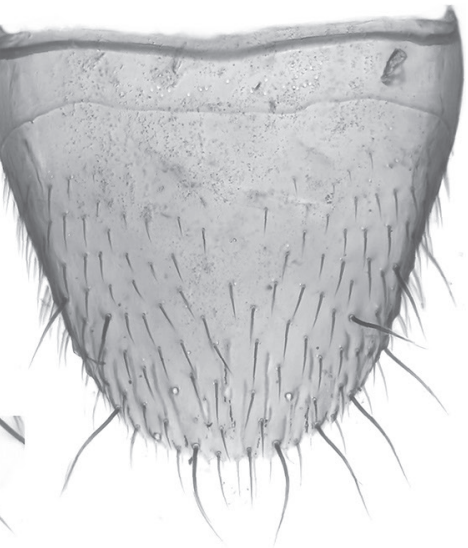

56

Figs 47-60: Atheta qinlingica (47-51) and A. biformis (52-60). 47-48, 52-54-median lobe of aedeagus in lateral and in ventral view (54: nanistic morph); 49, 56 - male sternite VIII; 50 - female sternite VIII; 51, 59-60 - spermatheca; 55 - male tergite VIII; 57 - female tergite VIII; 58 - posterior portion of female sternite VIII. Scale bars: 49-50, 55-58: 0.2 mm; 47-48, 51-54, 59-60: $0.1 \mathrm{~mm}$. 
pronounced microreticulation; punctation extremely fine; interstices with distinct microreticulation. Eyes small and flat, composed of eight ommatidia, situated dorso-laterally (i.e., both fully visible when viewed from above). Antennae moderately incrassate; antennomeres IV moderately transverse, $\mathrm{V}-\mathrm{X}$ of increasing width and increasingly transverse, $\mathrm{X}$ approximately twice as broad as long.

Pronotum (Fig. 5) 1.15 times as broad as long and as broad as head, broadest in anterior half; punctation very fine, but slightly more distinct than that of head; interstices with microreticulation.

Elytra (Fig. 5) barely half as long as pronotum; punctation fine and rather sparse; interstices with pronounced microsculpture. Hind wings completely reduced.

Abdomen broader than elytra; punctation fine and rather sparse; interstices with shallow microreticulation composed of predominantly transverse meshes on anterior tergites and of isodiametric meshes on posterior tergites; posterior margin of tergite VII without palisade fringe.

$o^{\top}$ : unknown.

क: tergite VIII with convex posterior margin; spermatheca (Fig. 24) with coiled proximal portion and with large and deep apical cuticular invagination.

Comparative notes: Bellatheta aucticeps is so distinctive based on external characters alone that a description based on a female appears justified. With no males available, however, the generic assignment should be considered tentative. The new species differs from all other micropterous representatives of the genus by its conspicuously large head, the position of the eyes, pale colouration, and by the shape of the spermatheca. For illustrations of other micropterous Bellatheta species reported from China see PACE (2004) and Assing (2002, 2009, 2011).

Distribution and natural history: The type locality is situated in the northern Gaoligong Shan, West Yunnan (Map 1). The holotype was sifted at an altitude of approximately $3030 \mathrm{~m}$.

\section{Bellatheta granulosa (PACE, 2004)}

Material examined: China: Shaanxi: $2 o^{\pi} o^{x}, 3$ 우, SW

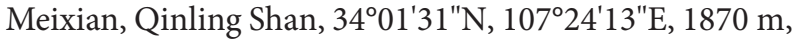
$\mathrm{N}$-slope, secondary deciduous forest, near stream, litter and grass sifted, 26.VII.2012, leg. Assing (cAss). Gansu: 1 ․, W-Qinling Shan, NW Longnan, Lazikou pass, S-side, Laolong valley, $34^{\circ} 08^{\prime} 14^{\prime \prime} \mathrm{N}, 103^{\circ} 51^{\prime} 57^{\prime \prime} \mathrm{E}$, $2300 \mathrm{~m}, \mathrm{~S}$-slope with pine and spruce forest, litter sifted, 3.VIII.2012, leg. Assing (cAss).

This macropterous species was previously known only from Gongga Shan in Sichuan (PACE 2004). The above material reveals that the species is widepread in China and represents the first records from Shaanxi and Gansu.

\section{Genus Atheta THOMSON, 1858, subgenus Microdota MULSANT \& REY, 1873}

Including the four species described below and a new synonymy, 85 species of Microdota are currently known from China (exclusive of Hong Kong) and 13 species have been reported from Taiwan. Nineteen of the Chinese and four of the Taiwanese species are micropterous (or most likely so) (see checklist).

\section{Checklist of micropterous Microdota species recorded from China and Taiwan}

Species are listed alphabetically. References are sorted alphabetically and by publication year.

The literature references are abbreviated as follows: A02 = Assing (2002); A04 = Assing (2004); A06 = Assing (2006); A09 = Assing (2009); A11 = Assing (2011); App = Assing (present paper); P95 = PACe (1995); P99 = PACE (1999); P04 = PACE (2004); P11b = PACE (2011b); P16 = PACE (2016); P17 = PACE (2017).

Doubtfully micropterous species are marked with an asterisk (“*”).

\begin{tabular}{|c|c|c|}
\hline Species & Distribution & References \\
\hline altincisa Assing, 2009 & China: Yunnan: Gaoligong Shan & A09, A11 \\
\hline $\begin{array}{l}{ }^{*} \text { amischoides Assing, } 2009 \\
=\text { wuliangensis PACE, 2017, syn. nov. }\end{array}$ & China: Yunnan: Wuliang Shan & A09, P16, P17, App \\
\hline bicoloricornis AssING, 2009 & China: Yunnan: Gaoligong Shan & A09, A11 \\
\hline biformis spec. nov. & China: Yunnan: Diancang Shan & App \\
\hline clarata spec. nov. & China: Yunnan: Gaoligong Shan & App \\
\hline detruncata Assing, 2009 & China: Yunnan: Gaoligong Shan & A06, A09, App \\
\hline dimorpha Assing, 2006 & China: Yunnan: Baima Shan, Meili Xue Shan & A06, A09, App \\
\hline elisa Assing, 2002 & China: Shaanxi: Daba Shan & A02 \\
\hline foliacea Assing, 2006 & China: Yunnan: Xue Shan & A06, A11 \\
\hline
\end{tabular}




\begin{tabular}{|l|l|l|}
\hline \multicolumn{1}{|c|}{ Species } & \multicolumn{1}{|c|}{ Distribution } & \multicolumn{1}{c|}{ References } \\
\hline formosanorum PACE, 1995 & Taiwan: Hsuehshan & P95 \\
\hline geostiboides Assing, 2004 & China: Yunnan: Zhongdian env. & A04 \\
\hline${ }^{*}$ guanxianensis PACE, 2011 & China: Sichuan: Qionglai Shan, Erlang Shan & P11b \\
\hline hailuogouensis PACE, 2004 & China: Sichuan: Gongga Shan & App, P04 \\
\hline hastata Assing, 2006 & China: Yunnan: Meili Xue Shan & A06 \\
\hline${ }^{*}$ megatheca PACE, 2011 & China: Sichuan: Daxiang Ling & P11b \\
\hline minica spec. nov. & China: Sichuan: Songpan env. & App \\
\hline miriapex PACE, 2004 & China: Sichuan: Emei Shan & App, P04 \\
\hline peinantamontis PACE, 2009 & Taiwan: Peinantashan, Alishan & App, P09 \\
\hline puetzi PACE, 1999 & China: Shaanxi: Qinling Shan & P99 \\
\hline qinlingica spec. nov. & China: Shaanxi: Qinling Shan & App \\
\hline taichungensis PACE, 1995 & Taiwan: Hsuehshan & P95 \\
\hline taiwanensis PACE, 1995 & Taiwan: Hsuehshan & P95 \\
\hline xueica Assing, 2006 & China: Northwest Yunnan & A06 \\
\hline
\end{tabular}

\section{Atheta (Microdota) miriapex PACE, 2004} (Figs 25-26)

Material examined: China: Sichuan: $10^{\star}, 2$ 우 우 1 ex., Emei Shan, $29^{\circ} 33^{\prime} \mathrm{N}, 103^{\circ} 20^{\prime} \mathrm{E}, 2340$ m, 17.VI.2010, leg. Grebennikov (CNC, cAss).

The original description is based on a unique male from Emei Shan (PACE 2004). The previously unknown female sexual characters are illustrated in Figs 25-26.

\section{Atheta (Microdota) hailuogouensis PACE, 2004}

Material examined: China: Sichuan: 3 우, Gongga Shan, NE-slope, $29^{\circ} 51^{\prime} \mathrm{N}, 102^{\circ} 02^{\prime} \mathrm{E}, 3170 \mathrm{~m}, 18 . \mathrm{VI} .2011$, leg. Grebennikov (CNC, cAss).

This species was described based on a male and a female from Gongga Shan (PACE 2004).

\section{Atheta (Microdota) dimorpha Assing, 2006}

Material examined: China: Yunnan: $60^{x} o^{x}, 8$ 우, $23 \mathrm{~km}$ SE Deqin, road G214, $28^{\circ} 20^{\prime} \mathrm{N}, 9^{\circ} 05^{\prime} \mathrm{E}, 4380 \mathrm{~m}$, 12.VI.2012, leg. Grebennikov (CNC, cAss).

The original description is based on material from three localities in Deqin County, North Yunnan (Assing 2006).

\section{Atheta (Microdota) detruncata Assing, 2006}

Material examined: China: Yunnan: 2 ㅇ ㅇ, North Gaoligong Shan, $27^{\circ} 47^{\prime} \mathrm{N}, 98^{\circ} 32^{\prime} \mathrm{E}, 3030 \mathrm{~m}, 24 . \mathrm{V} .2010$, leg. Grebennikov (CNC, cAss).
This species was originally described based on three females from a locality in Gongshan County, Gaoligong Shan, North Yunnan (Assing 2006). Subsequently, another female was reported from a close locality (Assing 2009).

\section{Atheta (Microdota) amischoides Assing, 2006}

Atheta (Microdota) wuliangensis PACE, 2016: 313; unavailable name (nomen nudum).

Atheta (Microdota) wuliangensis PACE, 2017: 300; syn. nov.

The original description of $A$. amischoides is based on four males from Wuliang Shan, Yunnan (Assing 2009). According to the original description of A. wuliangensis (PACE 2016, 2017), the type material of A. wuliangensis was collected in the same locality, on the same date, and by the same collector. This, as well as the illustrations of the aedeagus and the habitus of $A$. wuliangensis in PACE (2016) leave no doubt that the type material of both names is conspecific. Hence the synonymy proposed above.

\section{Atheta (Microdota) peinantamontis PACE, 2009 (Figs 6, 27-32)}

Material examined: Taiwan: $90^{\top} o^{\top}, 6$ 우 으, Chiayi Co., Alishan, road 18, km 92.5, Nat. Sc. Area, 2100 m, Cryptomeria litter, 11.IV.2009, leg. Vít (cAss).

The original description is based on five specimens from Kaohsiung Hsien, Peinantashan trail (PACE 2006). The above record reveals that the species is not locally endemic. The external and sexual characters of the material from Alishan is illustrated in Figs 6, 27-32. 
Atheta (Microdota) clarata spec. nov. urn:Isid:zoobank.org:act:EE3C4E47-FEAB-413A-81C7-A063529A5235 (Figs 7, 33-38)

Type material: Holotype $0^{\star}$ : "P.R. CHINA, Yunnan, E slope N Gaoligongshan, N2747'22.1" E98³2'17.7", 24.v.2010, 3027 m, sifting20, V. Grebennikov / Holotypus o Atheta clarata sp. n., det. V. Assing 2020" (CAS). Paratypes: $10^{\star}, 1$ i : same data as holotype (CNC, cAss).

Etymology: The specific epithet is the past participle of the Latin verb clarare (to tint) and alludes to the pale colouration.

Description: Body length $1.7-2.3 \mathrm{~mm}$; length of forebody $0.7-0.9 \mathrm{~mm}$. Habitus as in Fig. 7. Colouration: head reddish to brown; pronotum and elytra dark-yellowish to reddish; abdomen reddish to reddishbrown with tergite VI usually somewhat darker; legs yellow; antennae brown with the basal three antennomeres yellowish.

Head approximately as broad as long; punctation extremely fine; interstices with distinct microreticulation. Eyes small and flat, composed of approximately eight ommatidia. Antennae incrassate; antennomeres IV transverse, $\mathrm{V}-\mathrm{X}$ of increasing width and increasingly transverse, $\mathrm{X}$ approximately twice as broad as long.

Pronotum 1.15-1.20 times as broad as long and 1.151.20 times as broad as head; punctation similar to that of head, but somewhat denser; interstices with pronounced microreticulation.

Elytra little more than half as long as pronotum; punctation extremely fine; interstices with shallow microsculpture. Hind wings completely reduced.

Abdomen broader than elytra; punctation very fine, moderately dense on anterior tergites and sparse on posterior tergites; interstices with microreticulation composed of predominantly transverse meshes on anterior tergites and of isodiametric meshes on posterior tergites; posterior margin of tergite VII without palisade fringe; tergite VIII (Fig. 35) without evident sexual dimorphism, posterior margin weakly convex.

$\sigma^{\star}$ : sternite VIII (Fig. 36) moderately transverse, posterior margin strongly convex; median lobe of aedeagus $0.25 \mathrm{~mm}$ long and shaped as in Figs 33-34.

9 : posterior margin of sternite VIII with pronounced median incision and with moderately modified setae (Fig. 37); spermatheca (Fig. 38) with long and slender proximal portion.

Comparative notes: Atheta clarata is distinguished from the other two pale-coloured micropterous Microdota species known from China, A. geostiboides and A. bicoloricornis, by the primary and secondary sexual characters and additionally as follows:

- from A. geostiboides by slightly smaller size, significantly shorter and darker antennae, much finer punctation on the male head, the absence of a median sulcus and less fine punctation on the less transverse pronotum, finer punctation on the elytra, the shape of the male sternite VIII (more oblong and posterior margin truncate in A. geostiboides), and by a much smaller aedeagus;

from A. bicoloricornis by a less strongly microsculptured and consequently less matt head and pronotum, less distinctly bicoloured antennae, a less transverse pronotum, a convex posterior margin of the male tergite VIII (truncate in A. bicoloricornis), and by a smaller aedeagus of different shape. For illustrations of A. geostiboides and A. bicoloricornis see Assing (2004, 2009).

Distribution and natural history: The type locality is identical to that of Bellatheta aucticeps and situated in the northern Gaoligong Shan, West Yunnan. The type material was sifted at an altitude of approximately $3030 \mathrm{~m}$.

\section{Atheta (Microdota) minica spec. nov. urn:Isid:Z0obank.org:act:E325AF25-C1DD-441C-B7D5-AB2ACF109581 (Figs 8, 39-46)}

Type material: Holotype $\sigma^{\top}$ : "CHINA [22] - N-Sichuan, pass ENE Songpan, $4080 \mathrm{~m}, 32^{\circ} 44^{\prime} 54^{\prime \prime N}, 103^{\circ} 43^{\prime} 43^{\prime \prime E}$, sifted, 10.VIII.2012, V. Assing / Holotypus o Atheta minica sp. n., det. V. Assing 2020" (cAss). Paratypes: $2 \sigma^{\star} \sigma^{\star}, 1$ ㅇ: same data as holotype (cAss); 18 exs: same data, but leg. Schülke (MNB, cAss); $10^{\star}$ : "CHINA: N-Sichuan [CH12-19], 47 km N Songpan, road S 301 km $118, \mathrm{~N}$ Gongangling pass, $33^{\circ} 03^{\prime} 15^{\prime \prime} \mathrm{N}, 103^{\circ} 43^{\prime} 36^{\prime \prime} \mathrm{E}$, $3390 \mathrm{~m}$, spruce forest with shrubs, litter, moss, \& mushrooms sifted, 9.VIII.2012, leg. M. Schülke" (MNB); 1 ơ: "CHINA: N-Sichuan [CH12-24], 35 km NNW Songpan, $32^{\circ} 55^{\prime} 32^{\prime \prime} \mathrm{N}, 103^{\circ} 25^{\prime} 56^{\prime} \mathrm{E}, 3600 \mathrm{~m}$, moist N-slope with Salix and other shrubs, litter, grass roots \& moss sifted, 11.VIII.2012, leg. M. Schülke” (MNB).

Etymology: The specific epithet is an adjective derived from Min Shan, the mountain where the type locality is situated.

Description: Body length 1.7-2.4 mm; length of forebody $0.8-1.0 \mathrm{~mm}$. Habitus as in Fig. 8. Colouration: head blackish-brown to black; pronotum and elytra brown to dark-brown; abdomen black with segments III-IV reddish to brown and the apex (segments VIII-X) yellowish; legs yellow; antennae dark-brown to blackish-brown with the basal three antennomeres dark-yellow.

Head weakly transverse; punctation extremely fine, barely noticeable in the pronounced microreticulation. Eyes small and flat, composed of approximately ten ommatidia. Antennae moderately incrassate; antennomeres IV transverse, $\mathrm{V}-\mathrm{X}$ of increasing width and 
increasingly transverse, $\mathrm{X}$ approximately twice as broad as long.

Pronotum approximately 1.2 times as broad as long and 1.2 times as broad as head; punctation similar to that of head, but somewhat denser; interstices with pronounced microreticulation; pubescence directed anteriad along midline.

Elytra approximately half as long as pronotum; punctation less fine than that of head; interstices with microsculpture. Hind wings completely reduced.

Abdomen broader than elytra; punctation very fine, moderately dense on anterior tergites and sparser on posterior tergites; interstices with microreticulation composed of predominantly transverse meshes; posterior margin of tergite VII without palisade fringe; tergite VIII (Fig. 43) without evident sexual dimorphism, posterior margin weakly convex.

$\sigma^{*}$ : sternite VIII (Fig. 42) weakly transverse, posterior margin strongly convex; median lobe of aedeagus 0.25 $0.27 \mathrm{~mm}$ long and shaped as in Figs 39-41.

o: posterior margin of sternite VIII with pronounced, $\mathrm{V}$-shaped median incision and with moderately modified setae (Fig. 44); spermatheca (Figs 48-49) with long and slender proximal portion.

Comparative notes: Atheta minica is distinguished from other Microdota species by the primary and secondary sexual characters. For illustrations of micropterous consubgeners reported from China see Assing $(2002,2004,2006,2009,2011)$ and PACE (1995, 1999, 2004).

Distribution and natural history: The species was found in three localities to the north and northwest of Songpan, Northwest Sichuan. The specimens were sifted from litter, moss, and grass roots in a slope with scree and shrubs, in a moist slope with willow and other shrubs, and in a spruce forest with shrubs at high altitudes (3390-4080 m).

\section{Atheta (Microdota) qinlingica spec. nov. urn:Isid:zoobank.org:act:1590B986-DE95-458C-AFE3-71CC51AB4106 (Figs 9-10, 47-51)}

Type material: Holotype o : "CHINA [2] - S-Shaanxi, SW Meixian, Qinling Shan, $34^{\circ} 01^{\prime} 31^{\prime \prime N}, 107^{\circ} 24^{\prime} 13^{\prime \prime E}, 1870 \mathrm{~m}$, 26.VII.2012, V. Assing / Holotypus o Atheta qinlingica sp. n., det. V. Assing 2020" (cAss). Paratypes: $10^{\star}, 1$ \% : "CHINA [1] - S-Shaanxi, SW Zhouzhi, Qinling Shan, $33^{\circ} 44^{\prime} 02^{\prime \prime N}, 107^{\circ} 58^{\prime} 06^{\prime \prime E}, 1900$ m, 25.VII.2012, V. Assing" (cAss).

Etymology: The specific epithet is an adjective derived from Qinling Shan, the mountain range where the species was discovered.
Description: Body length 2.5-2.8 mm; length of forebody $1.0-1.2 \mathrm{~mm}$. Habitus as in Fig. 9. Colouration: head blackish-brown; pronotum brown; elytra yellowish-brown; abdomen brown with the posterior margins of tergites III-VI, the posterior portion of tergite VII, and the apex (segments VIII-X) yellowish; legs yellow; antennae brown with the basal three antennomeres paler.

Head (Fig. 10) distinctly transverse; punctation dense and very fine; interstices with microreticulation. Eyes flat and of moderate size, composed of approximately 50 ommatidia. Antennae weakly incrassate; antennomeres IV approximately as long as broad, $\mathrm{V}-\mathrm{X}$ of increasing width and increasingly transverse, $\mathrm{X}$ approximately 1.5 times as broad as long.

Pronotum (Fig. 10) approximately 1.2 times as broad as long and 1.2 times as broad as head; punctation similar to that of head, but somewhat denser; interstices with pronounced microreticulation.

Elytra (Fig. 10) $0.80-0.85$ times as long as pronotum; punctation fine, but more distinct than that of head and pronotum; interstices with microsculpture. Hind wings reduced to short stubs of approximately the length of elytra.

Abdomen broader than elytra; punctation very fine, moderately dense on anterior tergites and sparser on posterior tergites; interstices with microreticulation composed of predominantly transverse meshes; posterior margin of tergite VII with narrow palisade fringe; tergite VIII without evident sexual dimorphism, posterior margin weakly convex.

$\sigma^{*}$ : sternite VIII (Fig. 49) weakly transverse, posterior margin strongly convex; median lobe of aedeagus $0.47-0.48 \mathrm{~mm}$ long and shaped as in Figs 47-48; internal sac with sclerotized spine-shaped apical internal structures.

+ posterior margin of sternite VIII with pronounced median incision and with a dense fringe of modified setae (Fig. 50); spermatheca (Fig. 51) rather large.

Comparative notes: Based on the similar structure of the aedeagus, the similar modifications of the female sternite VIII, and the similar general shape of the spermatheca, Atheta qinlingica belongs to the same species group as $A$. miriapex and $A$. peinantamontis. It is reliably distinguished from other species of this group by the shapes of the primary sexual characters. For illustrations of micropterous Microdota species previously reported from China see Assing (2002, 2004, 2006, 2009, 2011) and PACE $(1995,1999,2004)$.

Distribution and natural history: The species was found in two localities in Qinling Shan, South Shaanxi. The specimens were sifted from litter, soil, and grass roots in moist mixed and secondary deciduous forests at altitudes of 1870-1900 m. 
Atheta (Microdota) biformis spec. nov. urn:Isid:zoobank.org:act:30A8940E-5B8A-4E27-997F-777E8FFF3E80 (Figs 11-14, 52-60)

Type material: Holotype o : "P.R. CHINA, Yunnan, E slope Cangshan at Dali, N2540'14.7" E100 06'12.0", 17.v.2010, 3827 m, sifting16, V. Grebennikov / Holotypus $\sigma^{\top}$ Atheta biformis sp. n., det. V. Assing 2020" (CAS). Paratypes: $7 \sigma^{\top} \sigma^{\top}, 26$ + $\%$ : same data as holotype (CNC, cAss); $90^{\star} o^{\star}, 21$ ㅇ ㅇ: "P.R. CHINA, Yunnan, E slope Cangshan at Dali, N2539'54.7" E10006'04.5", 19.v.2010, 3815 m, sifting19, V. Grebennikov" (CNC, cAss); $20^{\top} o^{\top}, 6$ ㅇ ㅇ: "P.R. CHINA, Yunnan, E slope Cangshan at Dali, N25 40.07.6" E10006'12.9", 19.v.2010, 3887 m, sifting18, V. Grebennikov" (CNC, cAss); 3 o o $0^{\top}, 15$ ㅇ ㅇ: "P.R. CHINA, Yunnan, E slope Cangshan at Dali, N25 39'54.4" E100 $05^{\prime} 53.0^{\prime \prime}$, 15.v.2010, $3991 \mathrm{~m}$, sifting14, V. Grebennikov" (CNC, cAss); $20^{\top} 0^{\text {T }}, 13$ ㅇ ㅇ: "P.R. CHINA, Yunnan, E slope Cangshan at Dali, N2540'24.1" E10005'57.6", 17.v.2010,

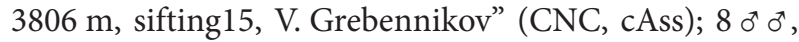
12 ㅇ : "P.R. CHINA, Yunnan, E slope Cangshan at Dali, N25 ${ }^{\circ} 40^{\prime} 01.9^{\prime \prime} \mathrm{E} 100^{\circ} 05^{\prime} 45.5^{\prime \prime}$, 15.v.2010, $4063 \mathrm{~m}$, sifting13, V. Grebennikov" (CNC, cAss): 2 ㅇ : "CHINA, Yunnan,

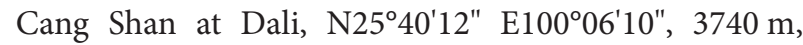
05.vii.2011, 4063 m, sift37, V. Grebennikov" (CNC).

Etymology: The specific epithet (Latin, adjective) alludes to the pronounced sexual dimorphism of the pronotum.

Description: Body length 2.3-3.3 mm; length of forebody 1.0-1.2 mm. Habitus as in Fig. 11. Colouration: head reddish to blackish; pronotum reddish to dark-brown; elytra dark-yellow to brown; abdomen brown to blackish with the apex (segments VIII-X and posterior portion of VII) usually yellowish to reddish and often also the anterior segments somewhat paler; legs yellow; antennae brown with the basal three antennomeres yellowish.

Head (Figs 12-13) distinctly transverse; punctation moderately sparse, subject to sexual dimorphism; interstices with microreticulation. Eyes flat and rather small, composed of approximately 15 ommatidia. Antennae weakly incrassate; antennomeres IV weakly transverse, $\mathrm{V}-\mathrm{X}$ of increasing width and increasingly transverse, $\mathrm{X}$ barely 1.5 times as broad as long.

Pronotum (Figs 12-13) 1.20-1.25 times as broad as long and 1.1-1.2 times as broad as head; punctation subject to pronounced sexual dimorphism; interstices with pronounced microreticulation.

Elytra (Figs 12-13) $0.60-0.65$ times as long as pronotum; punctation dense and asperate, partly granulose; interstices with microsculpture. Hind wings completely reduced.

Abdomen (Fig. 14) broader than elytra; punctation fine, but distinct, moderately dense on anterior tergites and sparser on tergite VI; punctation of tergite VII and VIII subject to sexual dimorphism; interstices with microreticulation composed of predominantly transverse meshes; posterior margin of tergite VII with or without indistinct rudiment of a palisade fringe; tergite VIII subject to sexual dimorphism.

$\sigma^{\top}$ : head (Fig. 12) flattened or impressed dorsally and with sparse and distinct punctation; pronotum (Fig. 12) with conspicuously dense and coarse punctation and with pronounced microsculpture rendering the disc nearly matt; tergite VII (Fig. 14) with granulose punctation in posterior portion; tergite VIII (Figs 14, 55) with dense and coarsely granulose punctation in posterior half, posterior margin truncate; sternite VIII (Fig. 56) nearly as long as broad, posterior margin strongly convex; median lobe of aedeagus usually $0.38-0.40 \mathrm{~mm}$ long (see notes on intraspecific variation) and shaped as in Figs 52-54.

o: head (Fig. 13) not flattened dorsally, with very fine punctation barely noticeable in the microsculpture; pronotum (Fig. 13) with very fine punctation and with moderately pronounced microsculpture, with subdued shine; tergite VII with fine and sparse punctation; tergite VIII (Fig. 57) with very fine punctation, posterior margin broadly convex; posterior margin of sternite VIII weakly concave and with fringe of long and moderately modified marginal setae (Fig. 58); spermatheca shaped as in Figs 59-60.

Intraspecific variation: One of the dissected males has an aedeagus of significantly smaller size $(0.33 \mathrm{~mm})$ (Fig. 54). This phenomenon (occasional occurrence of significantly smaller aedeagi) has been observed also in Schistoglossa curtipennis (Sharp, 1869) (J. Vogel, pers. comm.).

Comparative notes: Atheta biformis shares the conspicuous sexual dimorphism of the punctation of the head, pronotum, and apical tergites only with A. dimorpha (Baima Shan, Meili Xue Shan), evidently a synapomorphy suggesting that both species represent adelphotaxa. The new species is distinguished from A. dimorpha by larger body size, a broader habitus (head and pronotum more transverse), coarsely granulose punctation on the male tergites VII and VIII (less distinctly granulose in A. dimorpha), the shapes of the male tergite VIII and sternite VIII, a larger aedeagus (A. dimorpha: median lobe approximately $0.3 \mathrm{~mm}$ long) of different shape, and by the shape of the spermatheca. For illustrations of A. dimorpha see Assing (2006).

Distribution and natural history: The species was collected in rather larger numbers in Diancang Shan, North Yunnan, at high elevations $(3740-4060 \mathrm{~m})$. The sex ratio is strongly biased: only $25 \%$ of the specimens are males.

\section{Franzidota geostiboides (Assing, 2011), comb. nov.}

Platyola geostiboides Assing, 2011: $304 \mathrm{ff}$.

In the original description of Platyola geostiboides, which is based on a holotype and eleven paratypes from 
"China: Yunnan, Lincang Pref., Bangma Shan, $20 \mathrm{~km}$ NW Lincang", it was noted that the "habitus [was] somewhat unusual for Platyola" (Assing 2011). A revision of the type material revealed that the species in fact belongs to Franzidota PACE, 1982, a genus recently moved to the subtribe Meoticina of the Oxypodini (Assing 2020).

\section{Acknowledgements}

I am indebted to the colleagues listed in the material section, in particular Michael Schülke and Aleš Smetana, for the loan of material. Benedikt Feldmann (Münster) and Michael Schülke proof-read and reviewed the manuscript. Their helpful suggestions are much appreciated.

\section{References}

Assing, V. 2002: On some micropterous species of Athetini from Nepal and China (Coleoptera: Staphylinidae, Aleocharinae). - Linzer Biologische Beiträge 34 (2): 953-969.

Assing, V. 2004: A new microphthalmous Atheta species from Yunnan, China (Coleoptera: Staphylinidae, Aleocharinae). Linzer Biologische Beiträge $36(2)$ : 589-592.

Assing, V. 2005: On the taxonomy of some Palaearctic Aleocharinae (Coleoptera: Staphylinidae). - Linzer Biologische Beiträge 37 (1): 181-184.

Assing, V. 2006: Six new species of micropterous Atheta and Apimela from northern Yunnan, China (Coleoptera: Staphylinidae, Aleocharinae). - Linzer Biologische Beiträge 38 (2): 1143-1156.

Assing, V. 2009: New species and additional records of Homalotini, Athetini, Pygostenini, and Lomechusini from Yunnan, China (Coleoptera: Staphylinidae: Aleocharinae). - Linzer Biologische Beiträge 41 (1): 485-507.

Assing, V. 2011: Six new species and additional records of Aleocharinae from China (Coleoptera: Staphylinidae: Aleocharinae). - Linzer Biologische Beiträge 43 (1): 291-310.

Assing, V. 2020: Revision of the Apimela species of the Palaearctic Region with a focus on the West Palaearctic fauna, and with additional notes on the genus Franzidota (Coleoptera: Staphylinidae: Aleocharinae: Oxypodini). - Acta Musei Moraviae, Scientiae Biologicae 105 (1): 27-90.
Bernhauer, M. 1935: Neue Kurzflügler aus China. Entomologisches Nachrichtenblatt 9 (1): 3-14.

PACE, R. 1993: Aleocharinae della Cina (Coleoptera, Staphylinidae). - Bollettino del Museo Civico di Storia Naturale di Verona 17 [1990]: 69-126.

PACE, R. 1995: Descrizione di tre nuove specie orofile e attere del genere Atheta Thomson di Taiwan (Coleoptera Staphylinidae). - Nouvelle Revue d'Entomologie 12 (1): 57-62.

PACE, R. 1998a: Aleocharinae della Cina: Parte II (Coleoptera, Staphylinidae). - Revue Suisse de Zoologie 105 (2): 395-463.

PACE, R. 1998b: Aleocharinae della Cina: Parte IV (Coleoptera, Staphylinidae). - Revue Suisse de Zoologie 105 (4): 911-928.

PACE, R. 1999: Due nuove Aleocharinae orofile e microttere della Cina (Coleoptera: Staphylinidae). Beiträge zur Entomologie, Berlin 49 (2): 377-381.

PACE, R. 2004: Hygronomini e Athetini della Cina con note sinonimiche (Coleoptera, Staphylinidae). Revue Suisse de Zoologie 111 (3): 457-523.

PACE, R. 2009: Athetini di Taiwan: contributo alla conoscenza delle Aleocharinae (Coleoptera, Staphylinidae). - Bollettino del Museo Civico di Storia Naturale di Verona 33: 51-96.

PACE, R. 2011a: Biodiversità delle Aleocharinae della Cina: Athetini, prima parte, generi Lasiosomina, Hydrosmecta, Amischa, Alomaina, Paraloconota, Bellatheta, Nepalota, Pelioptera, Tropimenelytron, Berca e Amphibolusa (Coleoptera, Staphylinidae). Beiträge zur Entomologie, Keltern 61 (1): 155-192.

PACE, R. 2011b: Biodiversità delle Aleocharinae della Cina: genere Atheta Thomson (Coleoptera, Staphylinidae). - Beiträge zur Entomologie, Keltern 61 (2): 285-355.

PACE, R. 2016: Aleocharinae della Cina al "Naturkundemuseum" di Erfurt (Insecta: Coleoptera: Staphylinidae). - Vernate 35: 295-336.

PACE, R. 2017: Atheta (Microdota) wuliangensis nov. spec. [p. 300]. - In: PACE, R. \& Hartmann, M. 2017: Berichtigungen und Ergänzungen zum Artikel PACE "Aleocharinae della Cina al 'Naturkundemuseum' di Erfurt” (Insecta: Coleoptera: Staphylinidae). Vernate 36: 297-303.

Schülke, M. \& SmetanA, A. 2015: Staphylinidae. Pp. 304-1134. - In: LöвL, I. \& LöBL, D. (eds): Catalogue of Palaearctic Coleoptera. Volume 2. Hydrophiloidea - Staphylinoidea. Revised and updated edition. - Leiden, Brill: xxvi + 1702 pp. 